DOI: $10.2478 /$ lpts-2019-0031

\title{
NATIONAL ENERGY AND CLIMATE PLANS: IMPORTANCE OF SYNERGY
}

\author{
A. Zigurs, M. Balodis, P. Ivanova, \\ K. Locmelis, U. Sarma
}

Latvenergo JSC

12 Pulkveža Brieža Str., Riga, LV-1230, LATVIA

E-mail: maris.balodis@latvenergo.lv,polina.ivanova@latvenergo.lv

In the modern world, including the European Union, the Baltic States and Latvia, the power industry has a broad definition, area and content, several social life and economic existence, comfort and safety provision. It also covers the following segments: heat/thermal energy, transport/fuel, electricity, energy resources and their types, etc.

More competent and wider synergy among different energy sectors and power industry and other areas provides the option to solve the global problems, for example, the mitigation of climate changes and the provision of energy sustainability by reducing the production of greenhouse gases, increasing the use of renewable energy sources, achieving higher energy efficiency and providing the careful use of energy resources. The results of synergy are of economic importance; they provide the efficiency and competitiveness of costs.

In this paper, the necessity of synergy between renewables and conventional generation and synergy among energy sectors are considered to achieve the dimensions of national energy and climate plans.

Keywords: energy, infrastructure, national energy and climate plans, synergy

\section{INTRODUCTION}

People's existence is based on various forms and sources of energy, e.g., for lighting, heating, and transporting. In everyday life, various energy sources power devices. Fulfilling these objectives requires wiser energy use and effective sociopolitical measures to formulate rational national energy mix.

As outlined in Eurelectric Industry Vision, the energy system will be transformed to make it more responsive, resilient and efficient. It will be required to invest in clean power generation and transition-enabling solutions in order to reduce emissions and actively pursue efforts to become carbon-neutral before mid-century, 
taking into account different starting points and commercial availability of the main transition technologies. The key enablers are needed to achieve these ambitions [1].

The National Energy and Climate Plans are a key tool of the Energy Union Governance towards achieving the EU's 2030 climate and energy targets [2]: 1) at least $40 \%$ cuts in greenhouse emissions; 2 ) at least $32 \%$ share for renewable energy; 3 ) at least $32.5 \%$ improvement in energy efficiency.

National Energy and Climate Plans (NECPs) cover the five dimensions of the energy union for the period of 2021 to 2030 [3]: 1) energy security, which implies the reduction of energy dependence and energy import, diversification of energy suppliers, the increase of energy system flexibility; 2) internal energy market, which includes the expansion of power infrastructure (interconnections), the expansion and provision of energy transmission infrastructure; the provision of internal energy market operation; the decrease of energy poverty; 3) energy efficiency - the reduction of primary energy sources use, the reduction of energy use in final gross energy consumption; the improvements of building efficiency; the long-term strategy of building renovation; 4) decarbonisation of the economy greenhouse gas reduction; renewables increase and $\mathrm{CO}_{2}$ capture increase; 5) research, innovation and competitiveness - private and public research, the promotion of clean energy technologies, the improvement of competitiveness.

The achievement of NECP dimensions is going to bring new trends in power sectors, thus resulting in challenges related to electric utilities and the necessity of their response to these challenges, for example:

- Decarbonisation and electrification: in the latest study of Eurelectric "Decarbonisation Pathways" [4], it has been marked that decarbonisation is possible only through the wide electrification of the transport, heating and cooling sectors. We see a great progress in creation of charging infrastructure for electric vehicles in the Baltic States, but unfortunately there is a lack of coordination among different operators, payment systems and standards. The number of electric vehicles is still far below the necessary critical mass to make this business profitable. The most promising technologies in electric heating and cooling are heat pumps and chillers, which use latent heat from the environment. In combination with renewable resources, these are one of the greatest possibilities for reduction of primary energy consumption.

- Power system integration and synchronisation: for instance, the most important project for the power sector of the Baltic States is power system integration (synchronization) with the European Continental Network. It is not only political, but also technical challenge. Implementation of the synchronous connection with only one double circuit high-voltage alternating current (HVAC) line and one submarine high-voltage direct current (HVDC) cable potentially has a high risk of bringing the Baltic power systems into the state of island operation. With reduction of domestic generation capacity, it could be a quite worrying signal for security of electricity supply. Another challenge is the necessity to deliver ancillary services, such as primary frequency control (FCR - frequency 
containment reserve) and inertia, which before synchronisation are mostly provided by the Russian power system. Baltic power transmission system operators are trying to solve this problem independently, rather than creating a solid trading platform for ancillary services. Battery electric storage system could be used for multiple applications, including provision of ancillary services and enhancing performance of power plants. That is why Latvenergo Group is considering it as an option for one of its combined cycle gas turbine (CCGT) plants (Riga TPP-1).

- Sector coupling and energy storage solutions: Sector coupling is another industry trend to be seriously considered. It means energy conversion from one energy source to the other and very often with the purpose of energy storage. P2G (power-to-gas, such as hydrogen) and P2F (power-tofuels, such as methanol) generation have great prospective in the future. It could allow for much greater energy storage volumes than in heat storage facilities.

- Synergy from market liberalization and integration: Synergetic effect could be expected from market coupling. In the early 90 s, restructuring and liberalization of electricity markets started, followed by gas market deregulation. Nowadays more efforts are spent for enabling competition in district heating markets. In large district heating systems (DHS), it becomes possible and feasible. Likewise in electricity and gas markets, competition in the district heating will take place not only in wholesale (among heat producers), but also in retail (among heat suppliers) segments. With evolution of the $4^{\text {th }}$ generation DHS, also households and small enterprises will have an opportunity to feed their produced heat into the district heating network. For the utility, it is important to have a planning tool to optimize its operations in all three closely linked markets.

- Data management: rollout of smart meters and data management systems allow customers to obtain their load profiles, remotely disconnect their property from power supply, install microgeneration (such as solar panels) and make use of bidirectional power flows to benefit from net accounting system advantages. Digitalisation in the power sector will allow automating different technological processes and inventing different control and monitoring systems, which will continuously evaluate the equipment and provide recommendations for its maintenance. Smart meters also allow customers to receive dynamic pricing products from their electricity suppliers.

- Smart cities and technologies: future vision of smart houses assumes not only smart sensors (temperature, humidity, $\mathrm{CO}_{2}$ ), circuits (switching devices), regulators (heating \& cooling, lighting, shading), but also control of heat and electricity production for domestic use, as well as charging of electric vehicles.

- Future design of a power system may face transformation from centralized to more deregulated. Some customers or communities may have a wish to create their own microgrids. 
In this paper, the dimension "decarbonisation" is considered in detail. This dimension is developing very rapidly. For example, today, the five countries that comprise the Nordic region - Denmark, Finland, Iceland, Norway, and Sweden have progressive energy and climate policies that are perhaps the most ambitious in the world. Each is attempting to become entirely or mostly "fossil fuel free" or "carbon neutral" with Denmark, Sweden, and Norway committed to $100 \%$ renewable energy penetration, Finland $80 \%$, and Iceland $50 \%-75 \%$ [5].

Figures 1 and 2 reflect the forecast of Nordic electricity and heat production from 2013 to 2050 according to Carbon-Neutral Scenario (CNS) [6]. This scenario is developed taking into account the local abundant wind resources together with already existing dispatchable hydropower. Mainly wind and slightly solar power will displace the fossil and nuclear in electricity generation. In heat production, electricity is going to dominate, thus adding flexibility to an integrated power and heat system and phasing-out of oil-fired boilers.

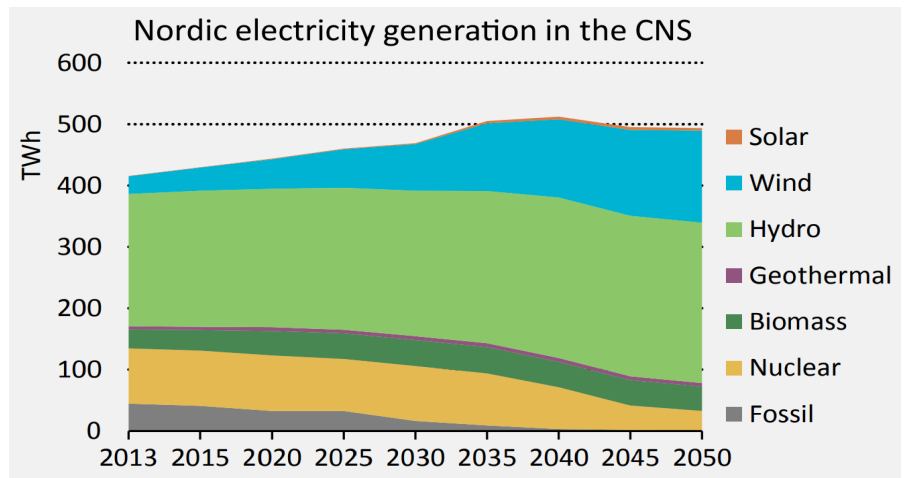

Fig. 1. Nordic electricity generation in the Carbon-Neutral Scenario, 2013-2050 [6].

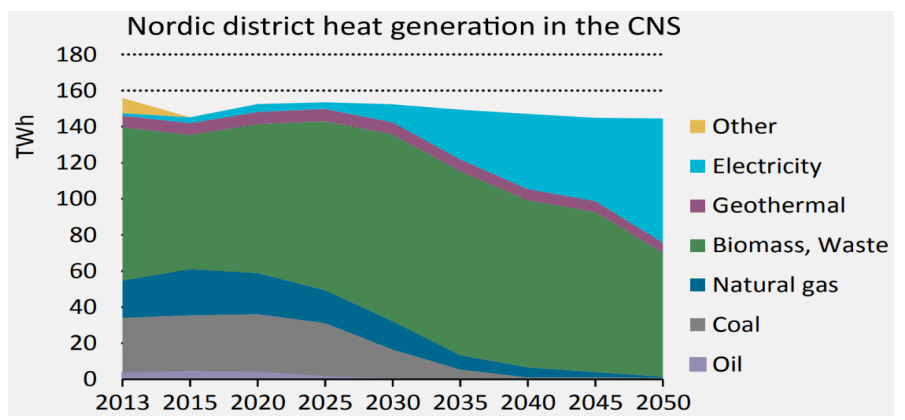

Fig. 2. Nordic district heat production in the Carbon-Neutral Scenario, 2013-2050 [6].

The scaled energy sector decarbonisation is characteristic of other countries, for instance, Germany, where electricity production from renewables (according to the installed capacity mainly solar and wind and less biomass and hydro) is still little behind the amount of electricity produced by fossil power plants (in line with the installed capacity mainly natural gas and coal and less nuclear), but overall trend is clear, i.e., the share of renewable generation is increasing and the share of fossil power plants is decreasing [7]. The questions to be addressed are "What challenges 
exist? and What broader lessons emerge from so rapid and scaled energy sector decarbonisation?"

The answers to these questions are reflected in Chapter 2. The main challenge is that the renewables threaten the existence of conventional generation, which has unfavourable consequences. The main lesson is that there must be the synergy between conventional generation and renewables.

In turn, Chapter 3 presents another synergy example - energy infrastructure cooperation (smart energy system) - which can help reach not only the decarbonisation dimension, but also other national energy and climate plan dimensions in a more proper way. For example, the electricity and gas systems interact continuously through a wide range of technologies, ranging from gas-to-power technologies (e.g., combined cycle gas turbine technologies) to power-to-gas technologies (e.g., electrolysis and methanation), via hybrid technologies (e.g., hybrid heat pumps). Closer cooperation between electricity and gas systems can help achieve climate goals in a more cost-efficient way by exploiting the synergies between the two systems [8].

During the period of 2025-2030 the electricity market of EU 28 might come to a state where average annual power demand could not be supplied by available conventional power plants (hydropower, natural gas, coal and nuclear). It is required to find solutions of major storage capacity of electricity generated by high-power, intermittent generation sources (wind and photovoltaics (PV)). Various mechanical, thermal, chemical and electro-chemical technologies are being studied worldwide.

Hydrogen has been deemed as one of the most promising energy carriers in more distant future. Extensive research efforts are devoted to resolve the issues of hydrogen storage. Accumulation and implementation of hydrogen reserves in existing power plants could ensure balancing of electricity consumption and production, adaptation to seasonal fluctuations and provision of energy reserves.

The ability to store hydrogen in a gaseous, liquid or solid state (as metal hydride) makes it suitable for projects of various scales. Hydrogen at various admixture levels can be directly injected into the existing natural gas grid. Electricity to the grid can be returned via gas turbines or fuel cell technology. Existing natural gas CCGT technologies can be readily adapted to operate on the admixture of natural gas and hydrogen.

However, estimated hydrogen electrolysis costs significantly exceed the price of natural gas, as well as a number of complex and unresolved technological and economic issues are raised:

- Injection of hydrogen into natural gas grid at a stable level;

- Hydrogen leak prevention;

- Storage and transportation solutions;

- Liquefaction of hydrogen gas;

- Safety and reliability issues.

More extensive use of hydrogen energy capabilities is projected after 2030.

Therefore, this article discusses approbated power generation technology solutions and opportunities. 


\section{RENEWABLES AND CONVENTIONAL GENERATION}

The largest source of $\mathrm{CO}_{2}$ emissions from the European OECD (Organisation for Economic Co-operation and Development) nations is energy, which accounts for $31 \%$ of emissions [9]. Climate mitigation goals (greenhouse gas reduction) must be taken skilfully for the development of energy sector, i.e., the synergy should be between conventional generation and renewables. However, the opposite situation is observed: different support schemes for renewable energy sources (such as feedin tariffs), large-scale integration of renewable energy sources and intermittent generation (solar photovoltaic, wind energy) in the energy production process and implementation of market mechanisms have changed [10], [11]:

- the running conditions of base load fossil fuel power plants (commercial conventional generation), i.e., the shifting from based load operation to cycling (new operation modes). It is the operation under variable condition, such as variable load of intermittent generation or fluctuation of electricity price. Baseload power plants are partly or entirely not adapted to the cycling operation, which leads to a decrease in their efficiency, more frequent trips and outages.

- the role of fossil fuel base load power plants, i.e., the secure integration of intermittent generation in energy production process and provision of regulation services to the transmission system operator instead of electrical and heat energy supply in line with its demand. This promotes the mass closing or mothballing of fossil fuel base load generation due to surplus of generation capacity, thus threatening the security of energy supply.

- the priority and significance of conventional generation. It is reflected in [10], [12], where the possible conflict was evaluated between the objectives of increasing the share of high-efficient cogeneration and renewable energy (biomass) using the example of Riga district heating system. The main consequences of conflict (natural gas cogeneration displacement with biomass), taking into account the situation in Latvia and neighbourly regions, were marked: decrease in primary energy savings; greenhouse gas emission increase; deterioration of electricity supply security; increase in the electricity price.

- the capability of conventional generation to participate in the development of wind generation. The reconstruction of fossil fuel power plants into biomass power plants and their mothballing provide unfavourable conditions for intermittent generation because a biomass generation unit has a lower flexibility level than commercial conventional generation (a natural gas power plant), which can excellently maintain electricity demand-supply balance. Moreover, biomass is an inefficient resource for electricity production. It is appropriate for heat energy production in terms of centralized and decentralized district heating system, where other more efficient power generation units are not used.

The excessive commitment to the climate mitigation issues have destabilised the energy sector triangle. It was emphasised by S. Ludge in [13]: "Out of three 
pillars describing the energy sector triangle only one is developing positively. This is the environmental part, with the greenhouse gas reduction ... and the increase of renewable energy production.... The other two pillars, being the cost competitiveness and the security of supply, are developing in the wrong direction".

This wrong direction results in mothballing of the existing based load power plants and suspension of new projects. For instance, Germany has decided to shut down all nuclear power plants. Some of the European Union (EU) countries decided to abandon coal generation in 5-10 years. Moreover, some EU countries are not planning to develop fossil fuel generation in the near future. Thus, "manageable" generating capacity is continuing to decline in the European power system. It is an alarm not only for European transmission system operators, but also for decisionmakers and politicians [7].

This trend is significantly critical for small quasi-isolated power systems. For example, the Baltic States are being currently integrated into the rest of EU electricity market mainly by direct current (DC) links. The integration of the Baltic States in Nord Pool has already brought substantial economic benefits for society through the decrease in the electricity price and price convergence among countries. However, penetration of renewable energy sources (RES) in production processes, in addition to electricity price fluctuations in some periods, has made the shift from base load to cyclical operation of fossil fuel power plants. The negative results appear in the decrease in power plant efficiency. It is vitally necessary to prevent these consequences, to adapt to a new situation and to achieve the dimensions of the national energy and climate plans in a more proper way. Penetration of renewables should be done deliberately and the flexibility of power plants should be enhanced [14].

Natural gas power plants are more advantageous than other conventional power plants (for example, brown coal or hard coal generation units) because they are more flexible, and natural gas is comparatively clean fossil fuel [15].

The flexibility of fossil fuel conventional generation is important not only today, but also within the next decades for the following reasons [10], [11]:

- to adapt existing generation to new running conditions and provide its efficient, flexible and profitable operation;

- to ensure the secure integration of intermittent generation in the energy production process and to ensure a stable energy system;

- to achieve the goal of the European Commission concerning renewable energy sources and energy efficiency.

The integration of renewables should be done competently preventing the displacement of conventional generation, i.e., there should be synergy between renewables and conventional generation in order to achieve climate mitigation goals without negative consequences.

There are different ways to achieve synergy between renewables and conventional generation, for example, the use of heat storage system to increase the flexibility of thermal power plants (TPP) and to adapt their operation to the variable operation conditions ensured by wide integration of renewables in the energy production process or by fluctuation of electricity price in the electricity market. 
The flexible thermal power plants provide a more secure integration of intermittent generation in the energy production process and an opportunity to participate in frequency control. For instance, Sandreuth thermal power plant (Germany, Nuremberg) is loaded more, when the power of intermittent generation is not enough. The produced electricity is delivered to the electrical power network and heat energy - to the heating network. The surplus of heat energy is accumulated in the storage tank for its later delivery to the heating network. When there is enough power of intermittent generation, the load of Sandreuth thermal power plant is reduced to the minimal value or power plant is shut down. The intermittent generation mainly provides the demand of electricity and storage tank - heat energy. Thermal power plant ensures the small part of heat energy and electricity demand [11].

If the variable operation conditions are ensured by changing of electricity price in the market as it is in case of Latvia (lack of intermittent generation), then the installation of heat storage system ensures [11] (Figs. 3 and 4):

- the replacement of operation in mixed mode with running conditions in cogeneration mode, which ensures a more effective operation of the cogeneration unit, i.e., the decrease in natural gas consumption and $\mathrm{CO}_{2}$ emission production;

- the increase of TPP competitiveness due to a decrease in fossil fuel power plant production costs;

- the extension of operation period, where thermal power plant electricity production costs are lower than the electricity price;

- the gain of additional profit from realisation of additionally produced electricity in the market.

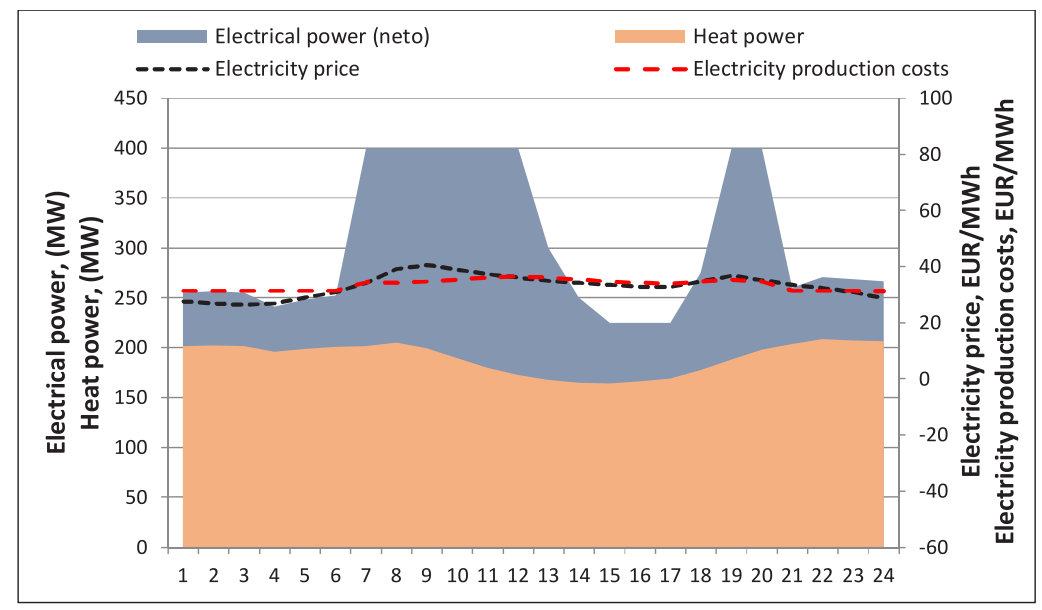

Fig. 3. Power of generation unit before the installation of heat storage system (one characteristic day) [11]. 


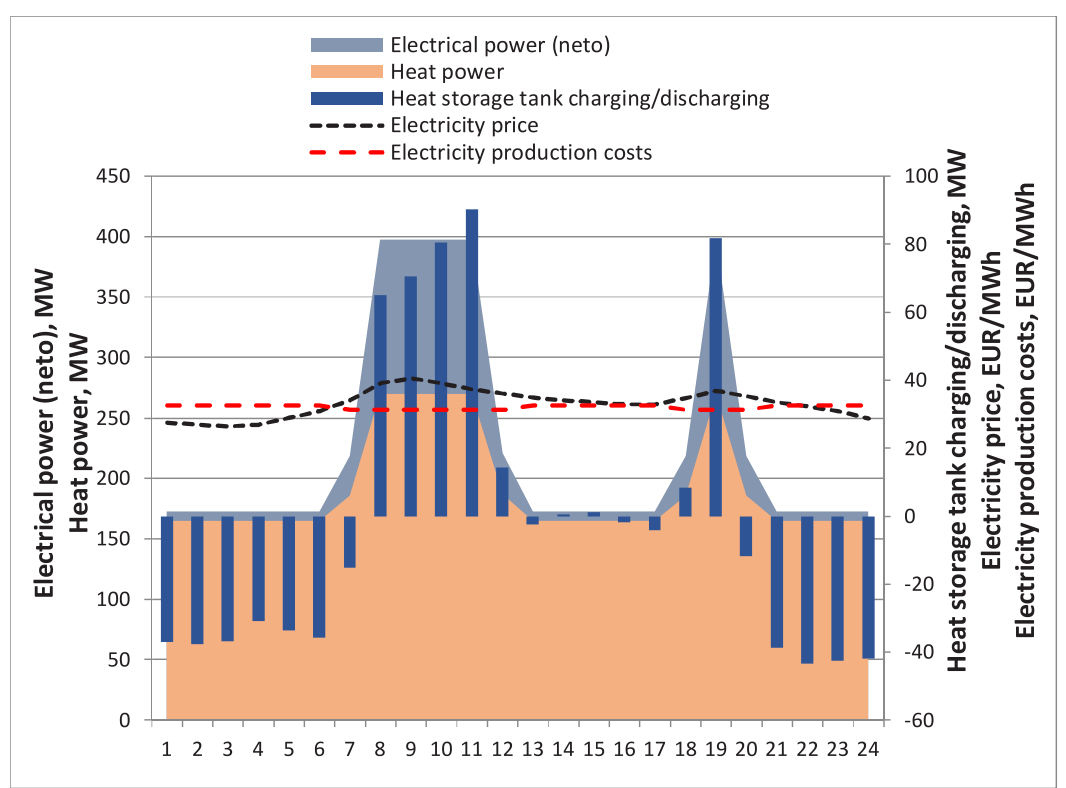

Fig. 4. Power of generation unit after the installation of heat storage system (one characteristic day) [11].

Formula (1) can be used to evaluate the amount of benefit $\left(\Pi_{k}\right)$ gained from the adjustment of TPP to the situation in electricity market by heat storage system [11].

$$
\begin{aligned}
& \Pi_{k}=\sum_{i}\left(m_{i} \times\left(\sum_{j}\left(\left(C_{j}-M C_{j}\right) \times P_{j}\right)-C_{\text {start }-u p}\right)_{i}\right)_{2}-\sum_{i}\left(m_{i} \times\left(\sum _ { j } \left(\left(C_{j}-\right.\right.\right.\right. \\
& \left.\left.\left.\left.M C_{j}\right) \times P_{j}\right)-C_{\text {start-up }}\right)_{i}\right)_{1},
\end{aligned}
$$

where $i$ - a characteristic day; $j$ - hour in a characteristic day; $m_{i}$ - the number of characteristic days (i) during a year, number; $C_{j}$ - the electricity price per hour, EUR/ MWh; $M C_{j}$ - the electricity production costs per $\mathrm{j}$ hour, EUR/MWh; $P_{j}$ - the supplied electricity per j hour, MWh; $C_{\text {start-up }}$ - start-up costs, EUR/start-up.

Another way to achieve synergy is the use of mathematical modelling instruments. Up-to-date forecasting and planning tools for the management of energy supply system are needed in order to ensure adequate and uninterrupted energy supply that complies with the requirements in respect to a secure supply system and environment. Energy system models are important instruments that allow analysing, forecasting, planning and optimally adjusting complex interactions between power engineering and environment, changes in technologies and energy consumption [10].

For example, in [10] the model has been created for the development of the energy system in Latvia, taking into account the specifics of energy supply in Latvia and the need to enable swift calculations (Fig. 5). The model comprises the possibility to analyse the evaluation of the integration of renewables on the operation of energy supply objects, the effect of resource prices, consumption dynamics, production capacities in energy resource generation, etc. The developed model comprises optimisation, system dynamics, econometric and algorithmic modelling elements. 


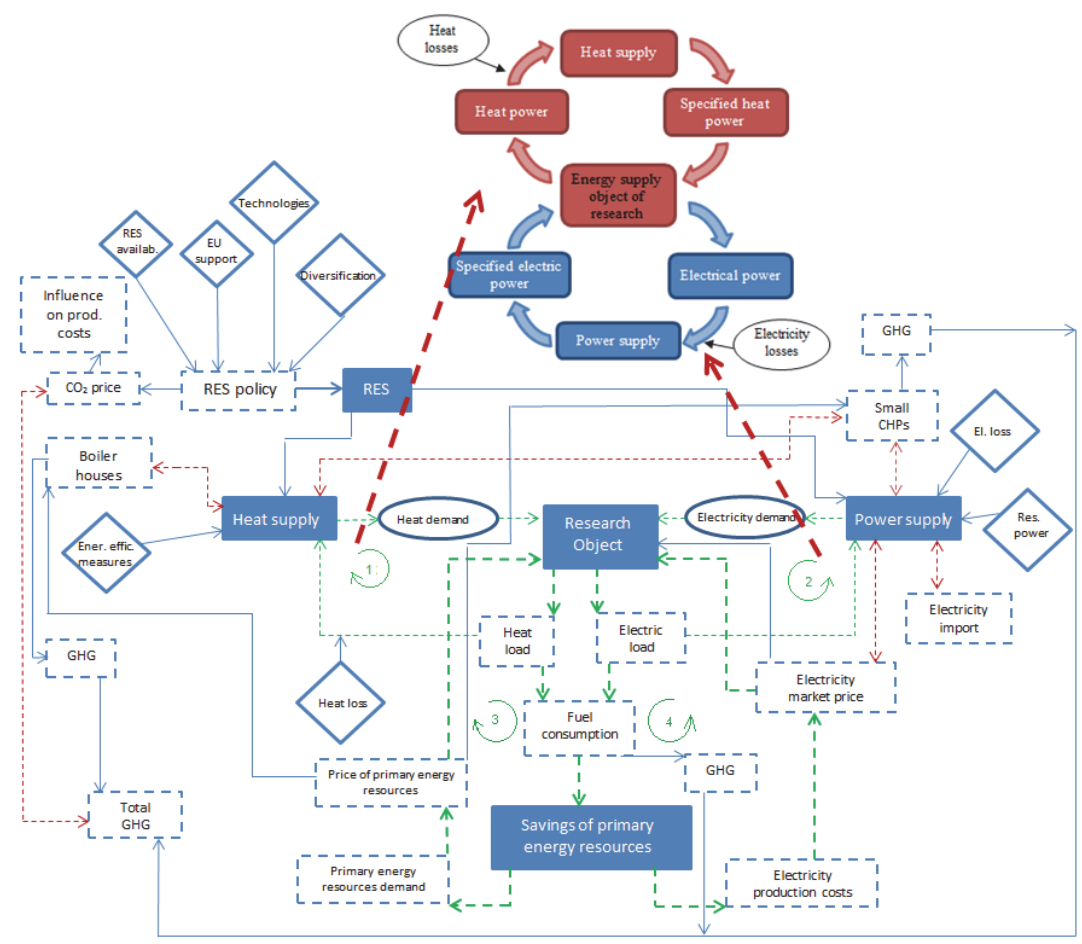

Fig. 5. Flowchart of the Latvian energy sectoral model [10].

The derived conclusions of modelling allow for a quicker evaluation of the quantitative indicators of the impact factors (e.g., wide renewable integration in energy production process) used for economic justification and management processes [10].

The practical modelling of the energy sector was accomplished considering the approbated technologies. In future, the modelling of optimal generation and accumulation might be supplemented with emerging technologies. Some of them, e.g., power-to-gas, are used in some research and pilot facilities. The analysis of forthcoming technologies might require significant tuning of the model in order to add more links among energy sectoral units. For instance, the electrolysis of hydrogen and methane production $\left(\mathrm{CH}_{4}\right)$ would allow for the continued use of existing natural gas infrastructure and applications, making extensive and revolutionary modernisation of power plants and appliances unnecessary.

\section{SYNERGY OF GRID INFRASTRUCTURES}

In simple terms, a smart energy system means combining the electricity, thermal and transport sectors so that flexibility across these different areas can compensate for the lack of flexibility from renewable resources, such as wind and solar power. The smart energy system is built around three grid infrastructures [16]:

- Electricity grids to connect flexible electricity demands such as heat pumps and electric vehicles to the intermittent renewable resources, such as wind and solar power. 
- Thermal grids (district heating and cooling) to connect the electricity and heating sectors. This allows for the utilisation of thermal storage in order to create additional flexibility and the recycling of heat losses in the energy system.

- Gas grids to connect the electricity, heating, and transport sectors. This allows for the utilisation of gas storage in order to create additional flexibility. If the gas is refined to a liquid fuel, then liquid fuel storages can also be utilised.

The infrastructures of different energy resources are both competitive and complementary. The development of a new project or reconstruction can optimise the relevant distribution networks. The heating of building can be provided by: 1) electricity (heat pumps or heaters); 2) natural gas (installing the natural gas heat boiler); 3) thermal energy from a district heating system.

For instance, it is possible to refuse from gas, if a district heating system is available and used. If the cheap natural gas is available, it is possible to install microgeneration and refuse from electricity. Different combination of technologies (synergy) is possible, for instance, electricity and gas or electricity and thermal energy. The synergy of technologies provides significant financial benefits. Solving this optimisation task, the human desires and preferences should be taken into account. This increases the number of possible combinations. The price of primary energy resources, the costs of equipment and manpower (including disassembling), the lifetime of equipment, the efficiency of energy conversion process and maintenance costs should be taken into account proving the calculation of year-round expenditures. Different variants of change in energy resource price can be applied. If calculation is provided for one variant, the return of investments can be calculated using the NPV (net present value) method. It can be complicated to use MS Excel for the calculation of many variants and combinations. Therefore, the calculation should be provided by iteration. As a result, the minimum of expenditures is found (minimum total costs).

In simple terms, it can be expressed by the following formula (2):

$$
Z_{i}=\sum_{t=1}^{T}\left(C_{j, t}+F_{j, t}+M_{j, t}-S_{j, t}\right),
$$

where $j$ - configuration; $t$-year; $Z$ - objective function; $C$ - capital investment; $F$ - fuel cost; $M$ - maintenance cost; $S$ - salvage value.

Providing the calculation and comparison of objective function for each configuration, the lowest minimum total costs are found.

Similar computation is performed at the utility level for least cost investment planning and optimal generation expansion planning of whole countries [17]. Specific software models can also perform the assessment of specific energy and environment policies and measures, including price signals, such as taxation, subsidies, emission trading system, technology promoting policies, renewable energy source supporting policies, efficiency promoting policies, environmental policies and technology standards. Such models are used to analyse how to meet policy targets and price or 
cost of driving policies [18]. The model reflected in Fig. 5 contains two analysis loops reflecting the interaction between heat energy production and electricity generation. One of the interim results is the calculated saving of primary energy resources. The research object includes the relation of heat and electricity demand and comprises the amount of resources transported.

It is desirable to perform similar optimisation to the whole surrounding area, because the costs of infrastructure of heating mains and natural gas pipelines are large and the payback time depends on the intensity of its use. Usually the trenches of electric cables, the ditches of gas pipelines and heating mains do not coincide and electric cables, gas pipelines and heating mains are in want of their own trenches or ditches.

It is possible to freight more efficiently supply networks and common infrastructure by proving the optimised use of energy resources. The increase in electrical power network load ensures the lowest specific fixed costs, which partly refer to the unit of energy. The current situation is that there are areas, where there are still consequences of the Soviet time socialistic planning. Proving the optimisation of electrical power network infrastructures, it is possible to achieve higher consumption density. For example, the use of distribution network in Latvia is $7408 \mathrm{GWh}$ (2018) / 93175 kilometre (2019) $=79.5$ GWh / thous. km. However, the use of connection power of electricity power networks accounts for average $7 \%$ in Latvia, but in the legal customers' sector - $16 \%$ [19]. Latvia is comparable to Hamburg in terms of population. The power distribution network in Hamburg includes around 29000 kilometres of power lines. The use of distribution network in Hamburg is 11.8 TWh / $29000 \mathrm{~km}=406.9 \mathrm{GWh} /$ thous. $\mathrm{km}[20]$. The network maintenance costs are lower in case of Hamburg. The connection power of electrical power network can increase significantly, if electrical technologies are used for heating.

\section{CONCLUSIONS}

The penetration of renewables is needed to ensure the energy mix and achieve the climate mitigation goals, but such penetration should be done deliberately in order to avoid undesirable consequences. However, nowadays the process of renewables mass penetration is launched and negative results are felt (the mass mothballing of conventional generation, the stability of energy supply is under the threat, the efficiency decrease of fossil fuel generation units, etc.). The reflected examples of synergies (cooperation between renewables and convention generation and cooperation among smart energy system grid infrastructures) present that it is vitally necessary to mitigate/prevent these negative results, to adapt to a new situation (variability of generation, new operation modes, urgency in ancillary services, lack of flexibility, etc.) and to achieve the dimensions of the national energy and climate plans in a more proper way.

\section{REFERENCES}

1. Eurelectric. (2019). Short Paper on the 2050 Objective. Available at https://www. eurelectric.org[08.07.2019] 
2. 2030 Climate and Energy Framework (n.d.). Available at https://ec.europa.eu/clima/ policies/strategies/2030_en [08.07.2019]

3. Kauliņ̌s, D. (2019). Presentation "Nacionālais energétikas un klimata plāns 2021. 2030. gadam" materials.

4. Eurelectric. (2018). Decarbonisation Pathways. Full study results. Part 1 - European Economy. Part 2 - European Power Sector. Available at https://cdn.eurelectric.org/ media/3558/decarbonisation-pathways-all-slideslinks-29112018-h-4484BB0C.pdf [08.07.2019]

5. Sovacool, B. K. (2017). Contestation, Contingency, and Justice in the Nordic LowCarbon Energy Transition. Energy policy. 102, 569-582.

6. IEA. (2016). Nordic Energy Technology Perspectives 2016. Cities, Flexibility and Pathways to Carbon-Neutrality. France: OECD/IEA. Available at https:// www.nordicenergy.org/wp-content/uploads/2015/12/Nordic-Energy-TechnologyPerspectives-2016.pdf [02.07.2019]

7. Balodis, M., Krickis, O., Gavrilovs, G., Sarma, U., Salcevičs, J., Lūsis, G., \& Linkevičs, O. (2018). VFB kongress un IERE seminārs Minhenē. Energija un Pasaule, 5(112), 20-25.

8. Artelys. (2018). Investigation on the interlinkage between gas and electricity scenarios and infrastructure projects assessment, pp. 1-43.

9. What are Europe's Biggest Sources of Carbon Emissions? (n.d.) Available at https:// www.weforum.org/agenda/2015/11/what-are-europes-biggest-sources-of-carbonemissions/ [02.07.2019]

10. Balodis, M. (2016). Optimisation model for securing energy supply towards sustainable economic development of Latvia. Riga: RTU.

11. Ivanova, P. (2018). The improvement of flexibility and efficiency of thermal power plants under variable operation conditions. Riga: RTU.

12. Kunickis, M., Balodis, M., Sarma, U., Cers, A., \& Linkevics, O. (2015). Efficient Use of Cogeneration and Fuel Diversification. Latvian Journal of Physics and Technical Sciences, 52(6), 38-47.

13. Ludge, S. (2017). The Value of Flexibility for Fossil-Fired Power Plants under the Conditions of the Strommarkt 2.0. VGB Powertech. 3, 21-24.

14. WEC 6th "Baltic Sea Round Table" (2019). Riga.

15. International Energy Agency. (2014). Energy Technology Perspectives 2014. Harnessing Electricity's Potential. France: OECD/IEA

16. Lund, H., Ostergaard, P., A., Connolly, D., \& Mathiesen, B., V. (2017). Smart Energy and Smart Energy Systems. Energy, 10.

17. International Atomic Energy Agency. (1995). Wien Automatic System Planning (WASP) Package. Vienna: IAEA.

18. E3MLab/ICCS. (n.d.). Primes Model 2013-2014. Athens: E3MLab.

19. AS "Sadales tīkls" izpilddirektora Sanda Jansona intervija ar aǵentūru "LETA", 13.06.2019. Available at https://www.sadalestikls.lv/sandis-jansons-jau-sobrid-jasakvertet-mazo-elektribas-razotaju-ietekmi-uz-elektrotiklu-un-izmaksam/ [11.07.2019]

20. Wie der Strom zu den Hamburgern kommt (n.d.). Available at https://www.stromnetzhamburg.de/ueber-uns/auftrag/das-stromnetz/ [11.07.2019] 


\title{
NACIONĀLAIS ENERG̣ETTIKAS UN KLIMATA PLĀNI: SINERG̣IJAS SVARĪGUMS
}

\author{
Ā. Žīgurs, M.Balodis, P. Ivanova, K. Ločmelis, U. Sarma
}

\section{Kopsavilkums}

Enerğija, enerḡêtika mūsdienu pasaulē, t.sk. Eiropas Savienības valstīs, Baltijā, Latvijā, u.c. ietver plašu jēdzienu, sfēru un saturu, vairākus mūsdienu sadzīves un tautsaimniecības eksistences, komforta un drošuma nodrošinājumu. Arī tā aptver tādus segmentus kā siltums/siltumenerǵija, transports/degviela, elektrība/ elektroenergija, energoresursi un to veidi.

Pareiza un plaša sinerǵija starp dažāaām enerǵêtikas jomām un enerǵêtiku un citām sfērām nodrošina iespējas risināt globālas problēmas, piemēram, klimata pārmaiņu mazināšana un ilgtspējīgas enerğijas izmantošanas nodrošināšana, samazinot siltumnīcefekta gāzu emisiju ražošanu, palielinot atjaunīgo energoresursu izmantošanā, sasniedzot lielāku enerğijas efektivitāti un nodrošinot saudzīgu energoresursu izmantošanu. Sinerǵijas rezultātiem ir ekonomiskais svarīgums, tā nodrošina izmaksu efektivitāti un konkurētspēju optimālajā veidā.

Šajā rakstā sinerǵijas nepieciešamība starp atjaunīgiem energoresursiem un konvencionālo generāciju un sinerğija starp dažādiem enerǵêtikas sektoriem tiek apskatìta, lai sasniegtu Nacionālā enerǵêtikas un klimata plānu dimensijas.

11.09.2019. 